\title{
Distribution of Betula pendula during late quaternary to present and characteristics of its lowest habitat in Turkey
}

\author{
Ünal Akkemik ${ }^{1}$, Besim Sertok ${ }^{2}$, Ferdi Akarsu ${ }^{1}$ \\ 1) Istanbul University, Faculty of Forestry, Department of Forest Botany 34473 Bahceköy-Istanbul, Turkey \\ 2) Forest Engineer, Sarlyer - Istanbul \\ Corresponding Author: uakkemik@istanbul.edu.tr
}

\begin{abstract}
Betula pendula L. is a forest tree species having local distribution areas in Turkey. When it had a wide distribution area during Late Glacial time of Turkey, its distribution decreased at the end of Late Quaternary. The purpose of the paper is to discuss its past and present distribution in Turkey, climate features in growing areas by focusing on the lowest distribution area in Turkey. This species has local distribution areas in mainly east of Turkey together with Kayseri-Erciyes Mountain. Though, the elevation of common distribution area of this species ranges between 1300-2850 $\mathrm{m}$ in Turkey, we focused on the lowest distribution areas in Munzur Valley 1333-1206 m a.s.1. The species grows with riparian trees (such as Salix caprea, S.alba, Alnus glutinosa etc.) on valley bottom having high level of ground water like wetland forest. In Marho Bridge and Joining Point of Mercan River, distribution of Tamarix gracilis ends and birch trees start to grow. In this altitude it is represented with small stands and individuals on the river banks. The study area located at bottom land with high level of ground water table and deep alluvial soil, and semi-dry climate. The reason of its presence here may be these optimum soil and water conditions. The distribution of the species ceases immediately with the disappearance of bottom land relief. Thus, that unique and special ecosystem should be protected as a whole.
\end{abstract}

Keyword: Betula pendula, silver birch, distribution, Munzur valley

\section{Introduction}

Due to having three great phytogeographic regions, which are the Mediterranean, Euxine-Colchis and Irano-Turanian, Turkey has distribution limits of some tree species such as Pinus sylvestris L, Quercus pontica L., Betula pendula L., and also hosts about 3.000 endemic plant species in junction areas of these three phytogeographical regions (Davis, 1965-1988; Güner et al., 2000).

B.pendula, which was subjected to the paper, is most commonly distributed one among the five Betula species in Turkey. Davis (1982) and Yaltırik (1988) explained that this species grows through Europe, Anatolia, West Siberia, Caucasian mountains, north and northwest of Iran, and north of Iraq. Within this great distribution area, B.pendula constitutes great forests in northern Europe, Russia, and Asia, while it has local forests and stands in southern Europe, southern Russia, Ukraine, Kazakhstan, Turkey, Georgia, Armenia, Iran and Iraq.

The southernmost border of its distribution is in the Elbruz Mountains of Iran at $2750 \mathrm{~m}$. Browicz and Zielinski (1982) stated that the northernmost distribution of the species is on $69^{\text {th }}$ latitude and easternmost is on $105^{\text {th }}$ longitude. In Turkey, the species grows at central, east and northeast mountains of Anatolia between 1200-2850 m elevations. Bottema (1990) stated that distribution of the species was wider in early Holocene than that of today in Turkey.

B.pendula trees grow on the volcanic soils in general (Browicz ve Zielinski, 1982). Avc1 (2004) stated that they may also grow on various types of soils because it has very wide distribution area in the world. 
B.pendula, which is a pioneer and high-competitive tree (Bottema, 1990), is also a species resistant to cold conditions but sensitive to drought. For that reason, it grows near to sea level in its northern growing regions, and 1500-3000 m a.s.l. in the southern areas. Browicz and Zielinski (1982) stated that this species has fragmented distribution areas between 1800-3000 m a.s.l in Iran, Iraq and Turkey, representing with small trees up to $10 \mathrm{~m}$ height.

Munzur Valley has the lowest elevation among the Betula species' southern distribution area (in Turkey, Iran and Iraq). By having a very rich biodiversity, Munzur Valley was assigned as a National Park in 1971. The criterion of Munzur Valley National Park is having (1) a huge plant diversity, (2) distribution of Betula trees, (3) a special kind of trouts, and (4) a very rich animal diversity. Furtherly, Munzur Valley was evaluated as one of the 122 "Important Plant Areas" of Turkey (Özhatay et al. 2005). In Munzur Valley, which coincides to B7 Square of Davis' system, detailed floristic studies were (Y1ldırıml, 1995; Davis, 1965-1985; Davis et al., 1988; Vitek et al., 2014, Karavelioğulları et al., 2014; Armağan, 2016; Yüce Babacan and Eker, 2017) performed and total 1522 taxa were identified. Within these taxa, 229 taxa endemic for Turkey and 46 of them are endemic for only Munzur Valley.

Woody flora of Munzur Valley is rather rich with the species birch trees (Betula pendula Roth, B. litwinowii Doluch.), oaks (Quercus L.), junipers (Juniperus excelsa M.Bieb., Juniperus oxycedrus L.), walnut (Juglans regia L.), willow (Salix alba L.), poplar (Populus nigra L.), alder (Alnus glutinosa (L.) Gaertn.) and maples (Acer tataricum L., and A. platanoides L.) (Ylldırıml, 1995). The purpose of the present paper is (1) to discuss the distribution area of B.pendula during Late Quaternary and at present and (2) to evaluate the ecological features of its lowest distribution area in Munzur Valley.

\section{Distribution of Betula in Late Quaternary of Turkey}

Pollen analyses performed on the fossil pollen from many locations in Turkey revealed important results for Betula. Bottema (1990) declared Betula distribution in Late Glacial/Holocene age for Turkey (Figure 1). In earlier Holocene time, the amount of Betula pollen is low in Turkey, except Van Lake. Van Lake records have a high amount of Betula pollen in this time. The pollen analyses done in Ova Lake and Gölhisar (Burdur) (Bottema and Woldring, 1984), Adıyaman-Gölbaşı and Urfa-Bozova (Zeist et al. (1968 (1970)) showed no Betula pollen in young Holocene. History of Betula in late Quaternary can be summarized as follows (Figure 1):

14.000-12.000 BP: The oldest Betula pollen records are from Lake Yeniçağa in the northwest, Samsun-Ladik in the central north and Karamık Marsh in the central west. The elevations of these areas range between 700-1000 $\mathrm{m}$ a.s.l. The climate was appropriate for growing of Betula and started to spread to treeless areas in $700-800$ meters.

12.000-10.000 BP: In this time interval Betula pollen was common in the west of Anatolia. The climate was getting better for Betula and it started to spread up to $1300 \mathrm{~m}$ a.s.l. in Abant Mountains. Pollen density in the lakes Abant, Yeniçağa, Karamık, Akgöl and Söğüt reached to its highest ratio at the end of this time. Pollen results confirmed that Betula forests started from 700-800 m a.s.l. (Figure 1).

10.000-8.000 BP: At the beginning of this time lag pollen density in the lakes, Abant, Akgöl and Söğüt reached its highest level and then started to decrease at the end of this time interval; their elevations were 1000 and $1400 \mathrm{~m}$. In this time Betula reached the widest area in Turkey and covered the tree lines in Abant Mountains, and around Lake Abant. After Betula, Abies dominated rapidly in mountains of Abant (Figure 1). While decreasing pollen density of Betula, Abies pollen density started to be dominant in west Anatolia.

8.000-6.000 BP: Betula pollen started to decrease rapidly in western $36^{\circ} \mathrm{E}$ latitude in Turkey. In this time eastern part (Nemrut Mountain-Söğ̈̈tlü-, Lake Van, and even in Lake Urmia in northern Iran (Bottema, 1986) have a considerable amount of Betula pollen. The pollen results confirmed that Betula forest moved to the east Anatolia in this time interval (Figure 1).

6.000-4.000 BP: During this time, amount of Betula pollen started to decrease in eastern Anatolia. Only a small amount of a revival of Betula pollen was found in Abant Lake in the west (Figure 1). 


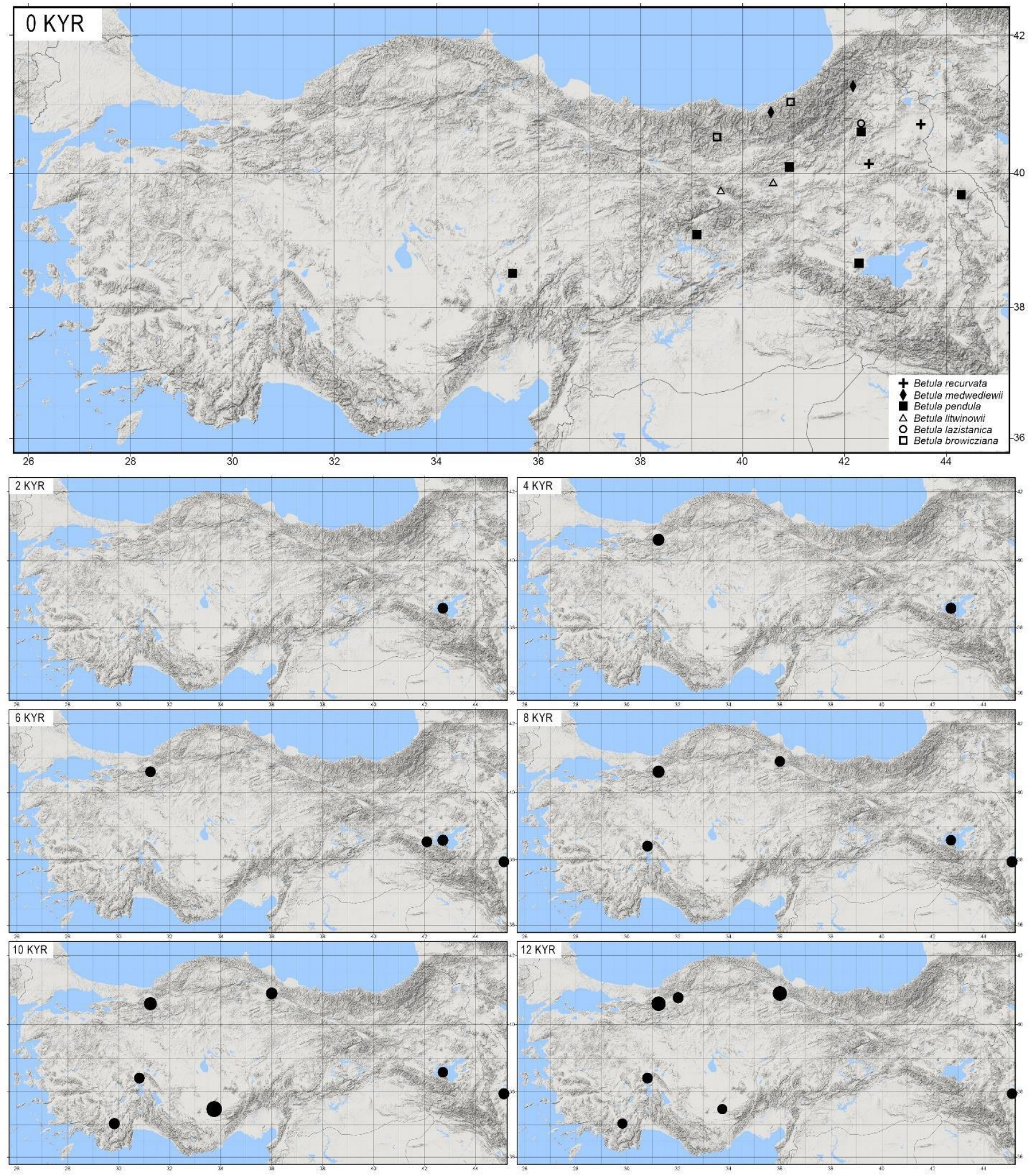

Figure 1. Betula pollen distribution during Late Quaternary in Turkey. (1 KYR= 1000 years Before PresentBP). Because pollen of Betula can be identificated as genus level, this data includes total pollen of all Betula species. Three dimensions of black circles can be seen in the last six small maps. Bigger one shows high amount of pollen, medium one shows middle amount of pollen, and small one indicates low amount of pollen.

4.000-2.000 BP: Betula pollen were seen again in Abant records. This time is second suitable interval for growing of Betula in northwest of Anatolia. Bottema and Woldring (1990) called this phase "Beyşehir Occupation Phase" and climate was near to optimum for Betula (Figure 1). 
2.000-Present: Betula trees are completely extincted from west Anatolia except only a limited distribution area in Kayseri-Erciyes Mountain $(2.400 \mathrm{~m})$. Local distribution areas remained in the east and northeast of Anatolia (Figure 1).

Bottema (1990) stated that Betula pollen data were represented by Betula pendula, because this is a pioneer species and has a competing role compared to other species.

\section{The present distribution of $B$. pendula}

B. pendula has a very wide distribution area in higher latitudes of Northern Hemisphere and small areas around Black Sea and Hazar Sea. Its south distribution limit is in northern Iran (Figure 3). This species grows between 1200-2800 m a.s.l. in Turkey, $2750 \mathrm{~m}$ a.s.l. in Elburz Mountain of northern Iran and in lower and higher latitudes (e.g. Kazakhstan, Siberia, northern Russia, and northern Europe) (Figure 2).

In Turkey, this species distributes north and northeast Anatolia together with an area in Erciyes Mountain. It constitutes mixture forests, and has not any pure forest in Turkey: A7 Trabzon: Değirmen Dere, 2100 m; A8 Erzurum: Kop Mountain pass, 2350 m; A9 Çoruh: Ardanuç, Sakaltutan Mountain, 2230 m; B5 Kayseri: Erciyes Mountain, Selimiye Gartrasu, c. 2800 m; B7 Tunceli: Ovacik, source of Munzur River, B8 Muş: Varto, foot of Bingel Mountain. at Gestemert G., 1585 m; B9 Bitlis: crater of Nemrut Mountain, 2400 m; B10 Ağrı: West side of Küçük Ağrı Mountain, 2500 m, often dominating on volcanic soils in the early stages of succession (Browicz, 1982).

Mayer and Aksoy (1998) explained that Sorbus aucuparia, Berberis integerrima, Juniperus communis, Ribes orientale, Rosa pimpinellifolia, Cotoneaster sp., Daphne oleoides, Epilobium angustifolium and Dactylis glomerata are the mixed species in 2200-2380 meters of Büyük and Küçük Ağrı Mountains. Schrub forms of Betula are seen up to 2780 m. At 2600-2800 m of Nemrut Mountain (Van Lake) the same form of trees are seen, and they constitute a mixed forest with Juniperus communis subsp.nana, Cotoneaster nummularia, Crataegus curvisepala, Rosa pulverulanta, Astragalus aureus and A.eriocephalus (Peşmen, 1973).

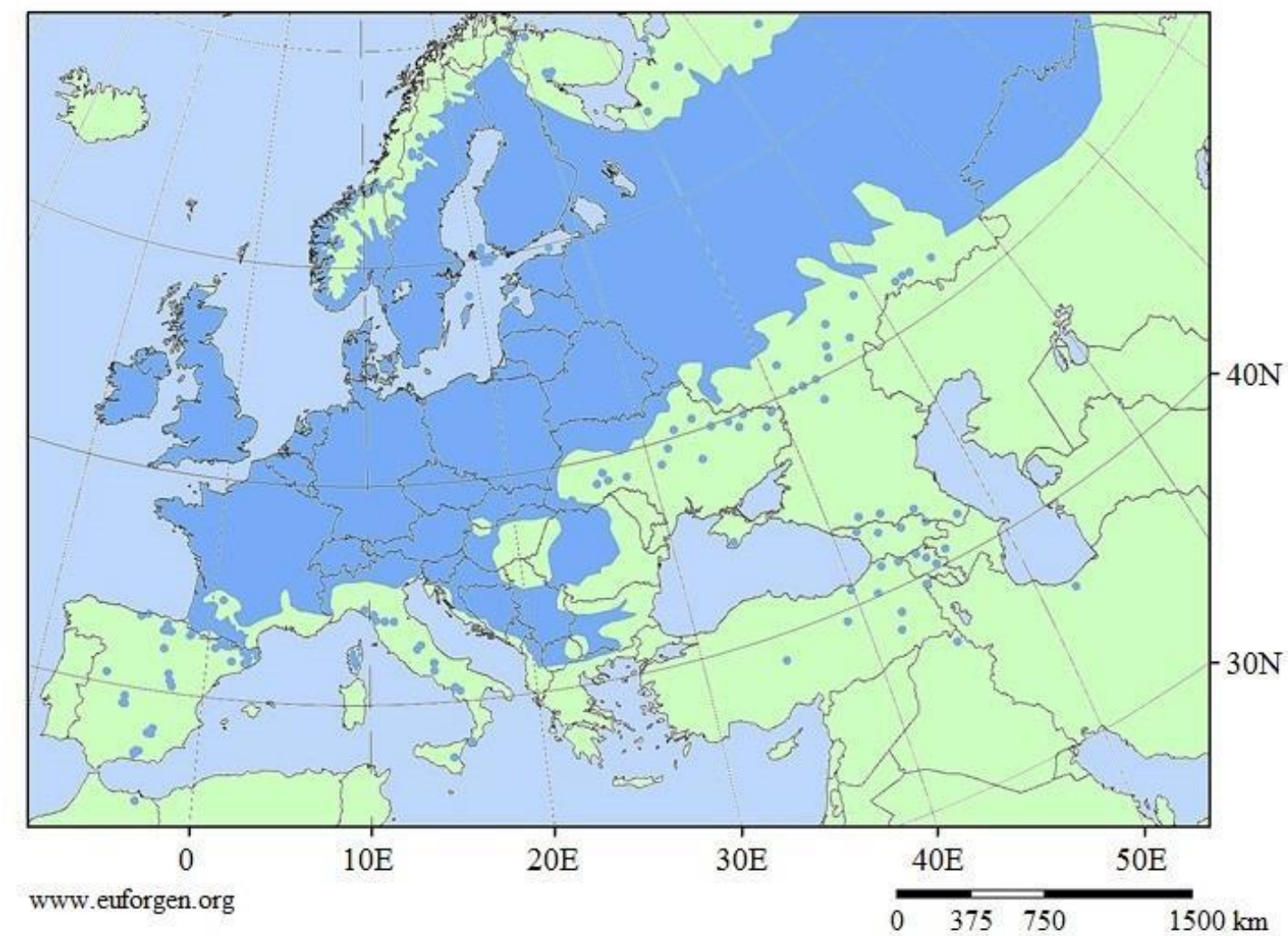

Figure 2. Distribution of Betula pendula in the world. It distributes mainly in higher latitudes and has local areas in the south (Caucasia, Turkey, Iran and Iraq) 


\section{The Climate of distribution areas}

According to Köppen's climate classification (Dönmez, 1984), all growing sites of B. pendula have "D Climate Belt" because mean minimum temperature of the coldest month is lower than $-3{ }^{\circ} \mathrm{C}$, and mean maximum temperature of the hottest month is over $10^{\circ} \mathrm{C}$. One of the most important climate factors of these sites is having high amount of snow coverage and soil freezing. Due to being wet through the year, climate type is Dfc (having a heavy winter, short and cool summer, and precipitation through the year). All sites have the same climate type according to the Köppen's climate classification.

According to the Erinç's climate classification (DMI, 1972), the climate of the growing areas in Turkey show different climate types from semi-humid to very humid (Table 1; Figure 3). Kayseri, Trabzon and Ağrı showed the same climate type "Semi-humid climate type". Bitlis and Muş have very humid climate type and Tunceli, Erzurum and Artvin are humid. Lowest mean of minimum temperature is $-11.9{ }^{\circ} \mathrm{C}$ in Artvin, and highest mean of maximum temperature is $27.7{ }^{\circ} \mathrm{C}$ in Munzur Valley. The highest differences in climate parameters may be seen between Munzur Valley and Artvin (Figure 3). The growing areas in Artvin have a high amount of precipitation no water deficit exist. On the contrary Munzur Valley has a high temperature and low precipitation during summer time.

Table 1. Classification of climate calculated using Erinç Formula*. The numbers in Table show precipitation index.

\begin{tabular}{cccccccc}
\hline Kayseri & Trabzon & Bitlis & Ağrı & Tunceli & Erzurum & Artvin & Muş \\
\hline 30 & 39 & 60 & 30 & 49 & 40 & 54 & 56 \\
Semi-humid & Semi-humid & $\begin{array}{c}\text { Very } \\
\text { humid }\end{array}$ & $\begin{array}{c}\text { Semi- } \\
\text { humid }\end{array}$ & Humid & Humid & Humid & $\begin{array}{c}\text { Very } \\
\text { humid }\end{array}$ \\
\hline
\end{tabular}

*According to Erinç Formula, 0-8 very dry, 8-15 is dry, 15-23 is semi-dry, 23-40 is semi-humid, 40-55 is humid, $55<$ very humid.

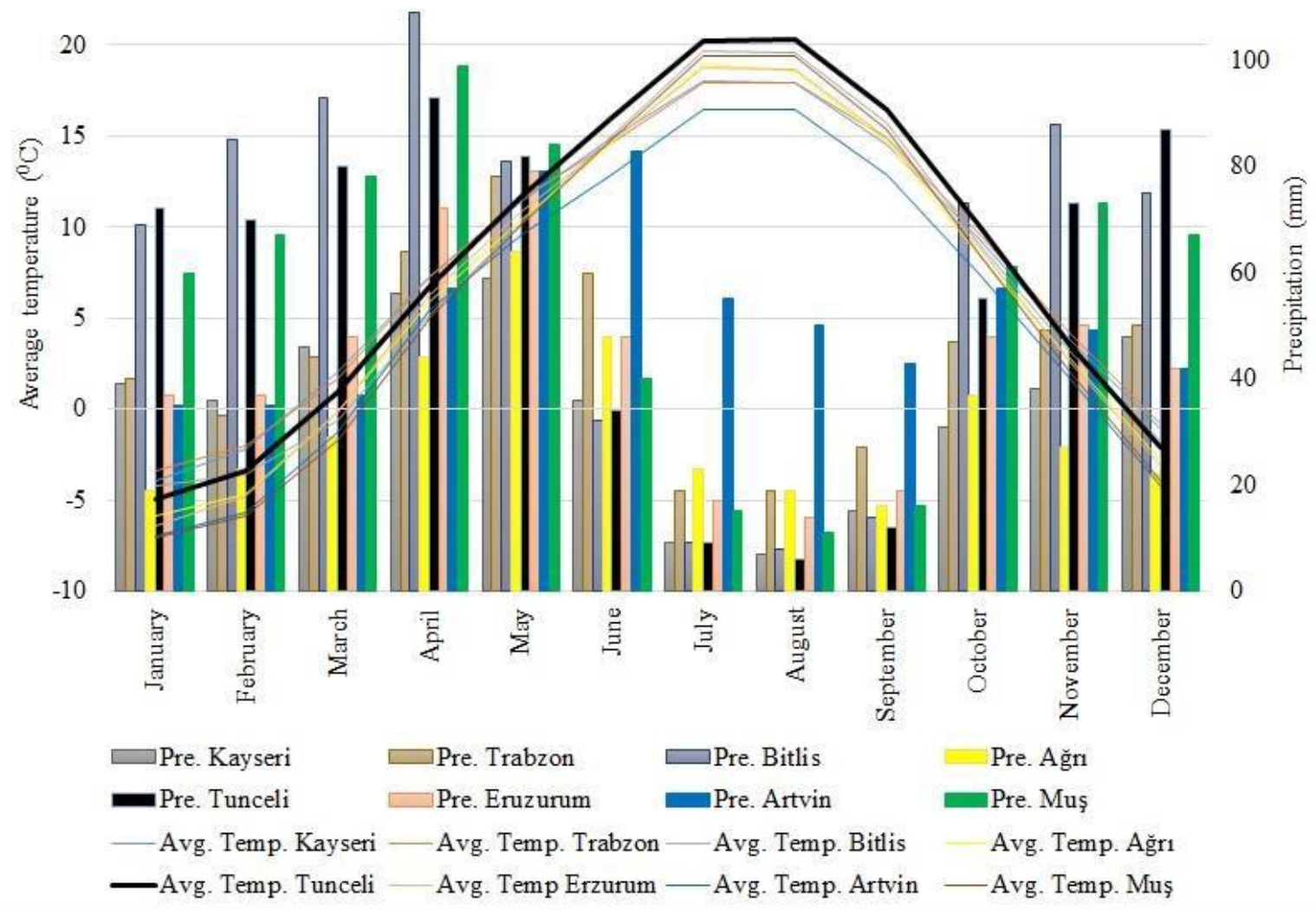

Figure 3. Climate diagrams of the distribution areas in Turkey 
Maximum, mean and minimum temperatures in the coldest (January) and hottest (August) months are seen in Figure 4. Maximum, mean and minimum temperatures in August range around $25^{\circ} \mathrm{C}$, mean $15-20{ }^{\circ} \mathrm{C}$ and around $10^{\circ} \mathrm{C}$, respectively. The hottest site is Munzur Valley in August. Maximum, mean and minimum temperatures in January are 1 to $-2{ }^{\circ} \mathrm{C}$, -4 to $-8{ }^{\circ} \mathrm{C}$, and -8 to $-12{ }^{\circ} \mathrm{C}$, respectively. The coldest growing area in the distribution area of B. pendula is in Artvin. Minimum temperature is moderate in Munzur Valley, which is its lowest distribution area (Figure 4).

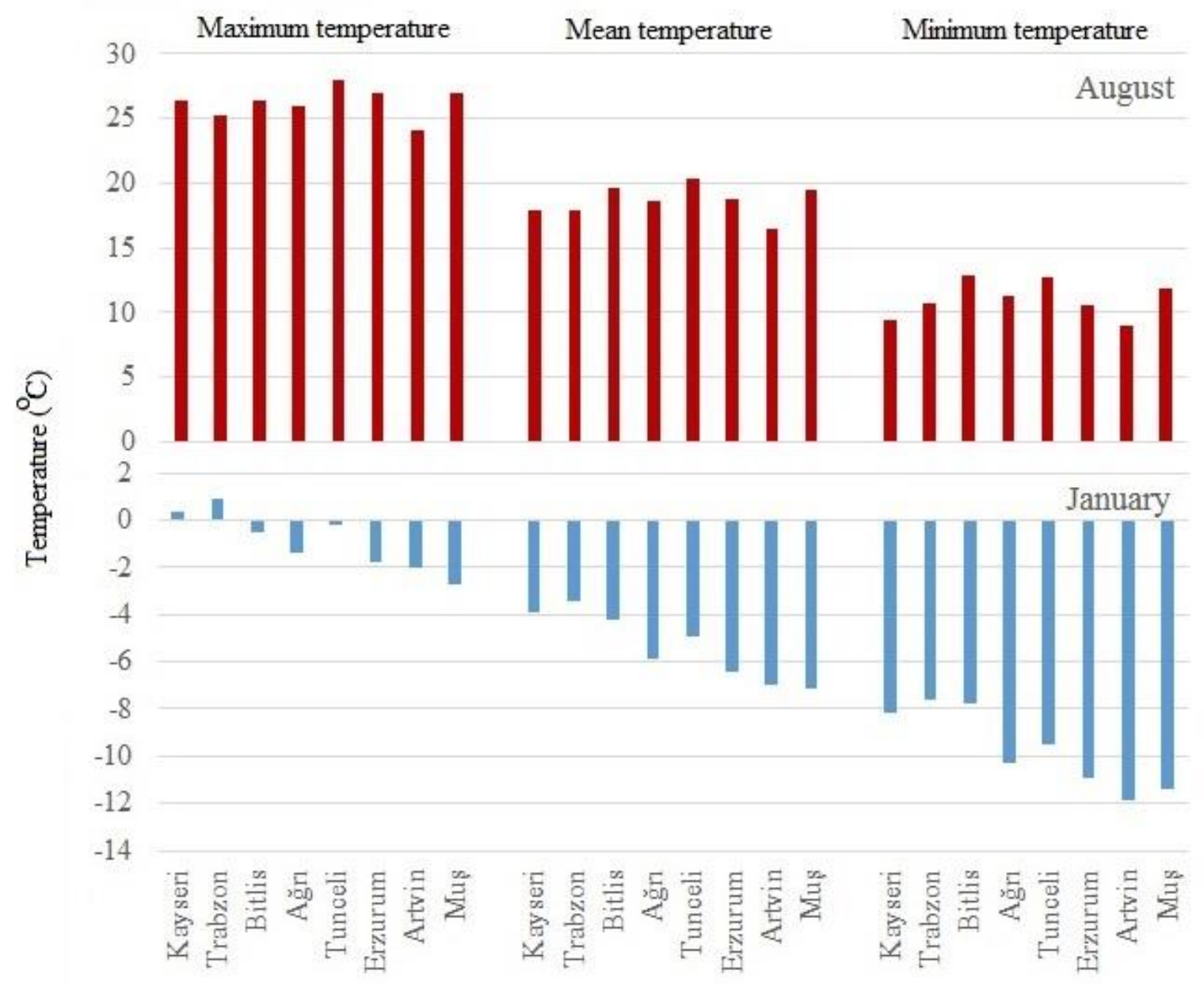

Figure 4. Maximum, mean and minimum temperatures of the distribution areas of Betula pendula trees in August (up) and January (low)

\section{Results and discussion}

This species grows in a very wide ecological amplitude from Siberia to Iran and throughout northern Hemisphere, and from sea level to $3000 \mathrm{~m}$ a.s.l. Our findings show that the lowest distribution area of the species in Turkey, Iraq and Iran is the Munzur Valley. The altitude of the lowest distribution is $1206 \mathrm{~m}$ and the species is represented with small riparian vegetation as small forest stands and individual trees. It grows from springs (1333 m a.s.l) down to $1206 \mathrm{~m}$ a.s.l. in Munzur Valley.

Munzur Valley has a bottom and flat area between steep slope hills around the city of Ovacik (Figure 5). Probably eroded soil was accumulated to this wide plain and soil depth increased over the time. Because the area is nearly flat, flow rate of the Munzur River is rather slow here. This condition may create an optimum growing area for B.pendula trees here. Because, the trees grow only on river banks and the bottom flatness around the river, having high level of ground water and similar to wetland (Longoz) forest conditions. 


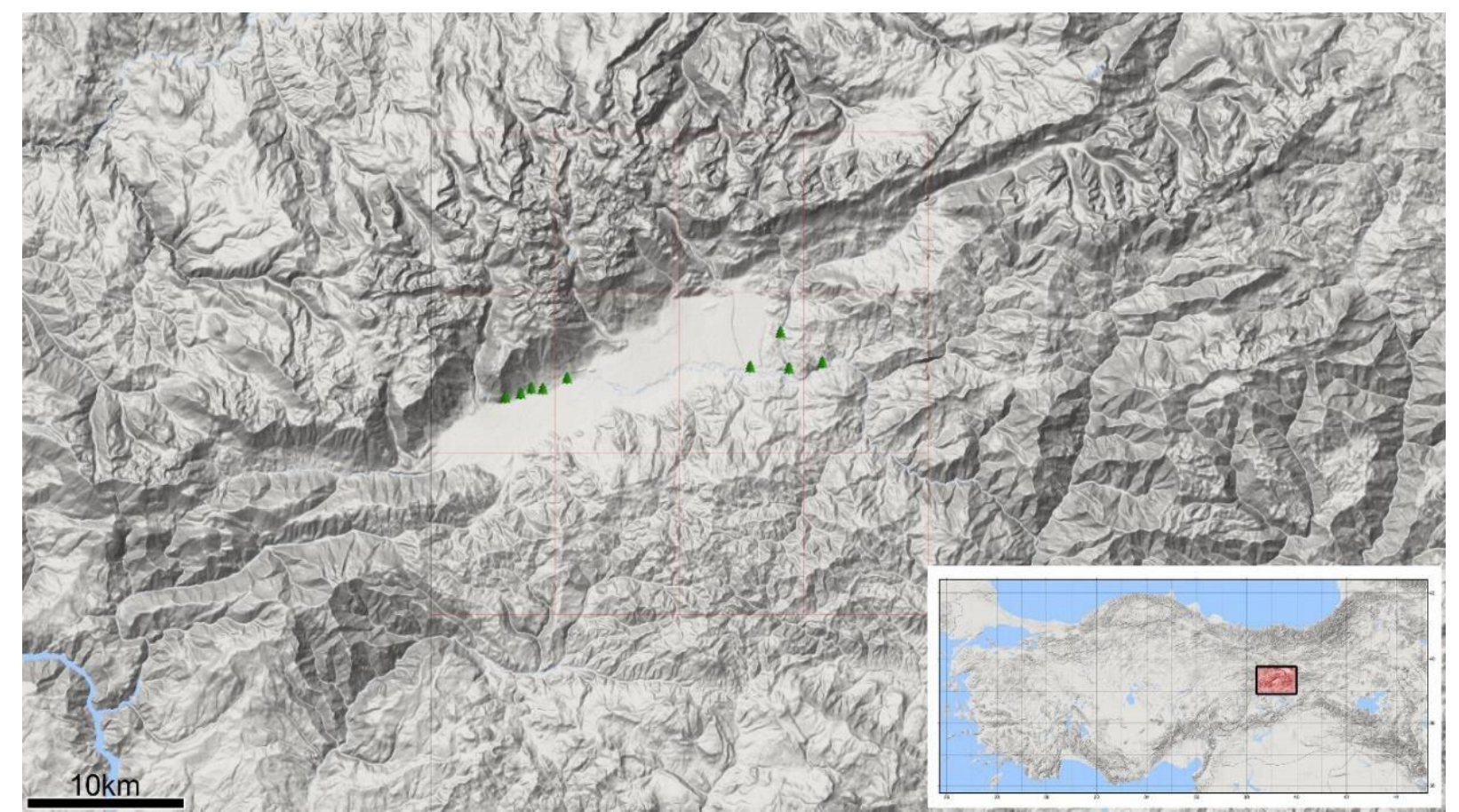

Figure 5. A general view of the distribution area of B.pendula in Munzur Valley.

Detailed observations on the presence of B.pendula from the spring to down in Munzur Valley were given as follows (Figure 6):

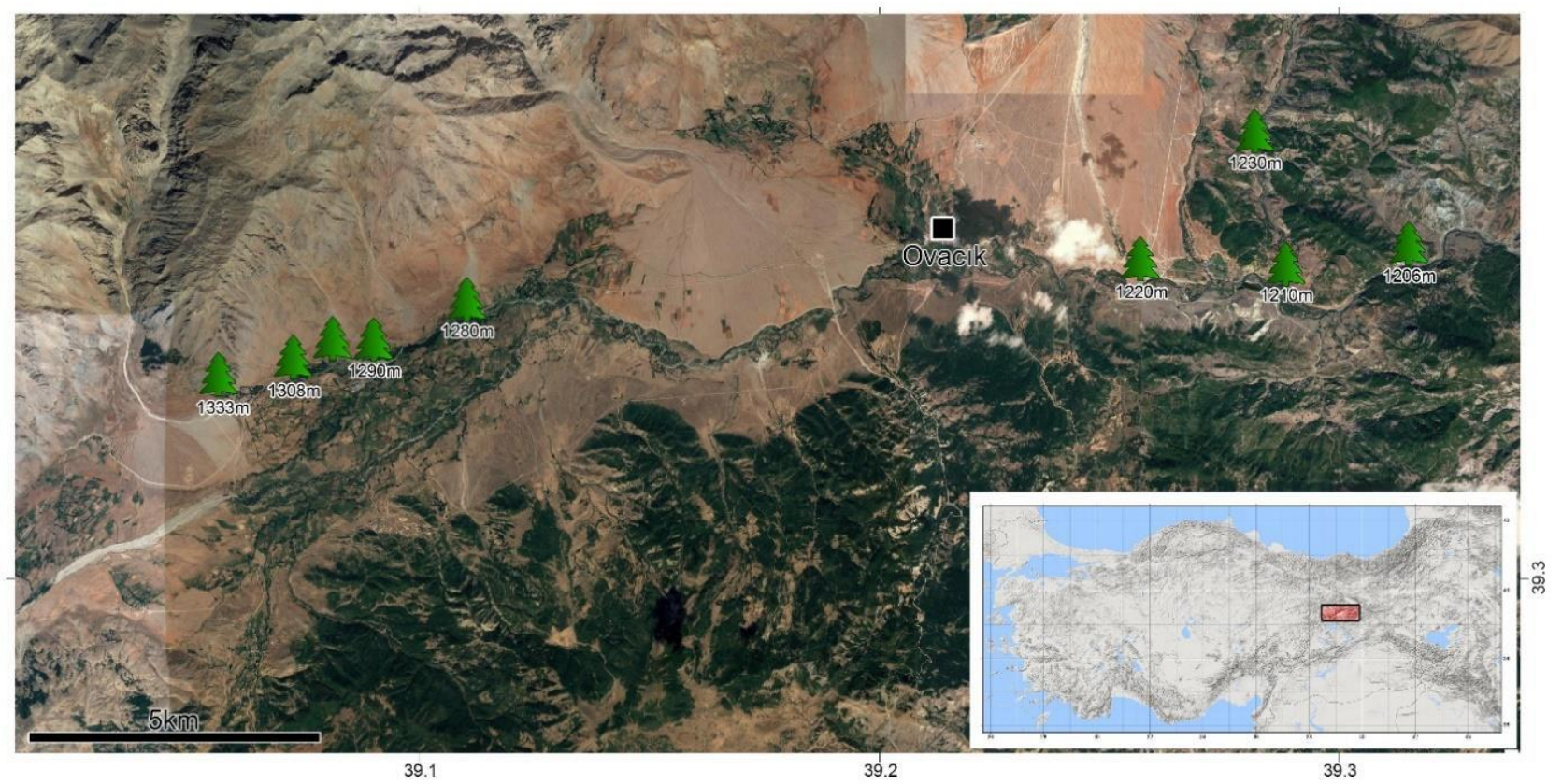

Figure 6. The locations of the B.pendula in the Munzur Valley

1. Kırkgözler/Munzur Springs $\left(39^{0} 19^{\prime} 51^{\prime \prime} \mathrm{N}-39^{\circ} 03^{\prime} 22^{\prime \prime}\right.$ E / altitude is $\left.1333 \mathrm{~m}\right)$ : In this site young Betula pendula trees grow of which diameters of breast hight $(\mathrm{DBH})$ of the trees are less than $8 \mathrm{~cm}$ and may be plantation. B. pendula trees grow with Quercus cerris, Ulmus glabra, Acer monspessulanum subsp. ibericum, Populus nigra, Salix alba and Juglans regia.

2. Yeşilyazı Village ( $39^{\circ} 20^{\prime} 02^{\prime \prime} \mathrm{N}-39^{\circ} 04^{\prime} 21^{\prime \prime} \mathrm{E}$ and $39^{\circ} 20^{\prime} 12^{\prime \prime} \mathrm{N}-39^{\circ} 04^{\prime} 54^{\prime \prime} \mathrm{E} /$ altitude is $1308 \mathrm{~m}$ ): After $800 \mathrm{~m}$ from Ziyaret Village down to Yeşilyazı Village a rectangular Betula pendula stand exists 
at approximately $100-150 \mathrm{~m}$ width and $750-800 \mathrm{~m}$ length. According to the Management Plan of Forest Service, the area covers 3 ha. This stand has old trees up to $1 \mathrm{~m}$ in DBH and $20 \mathrm{~m}$ height. Because of having a dense canopy closure, no woody vegetation was observed under the canopy, and Salix alba trees around the stand grow. In May $18^{\text {th }}, 2017$, level of groundwater was rather high and most of the stand soil was under water like a wetland forest (Figure 7 and 8).

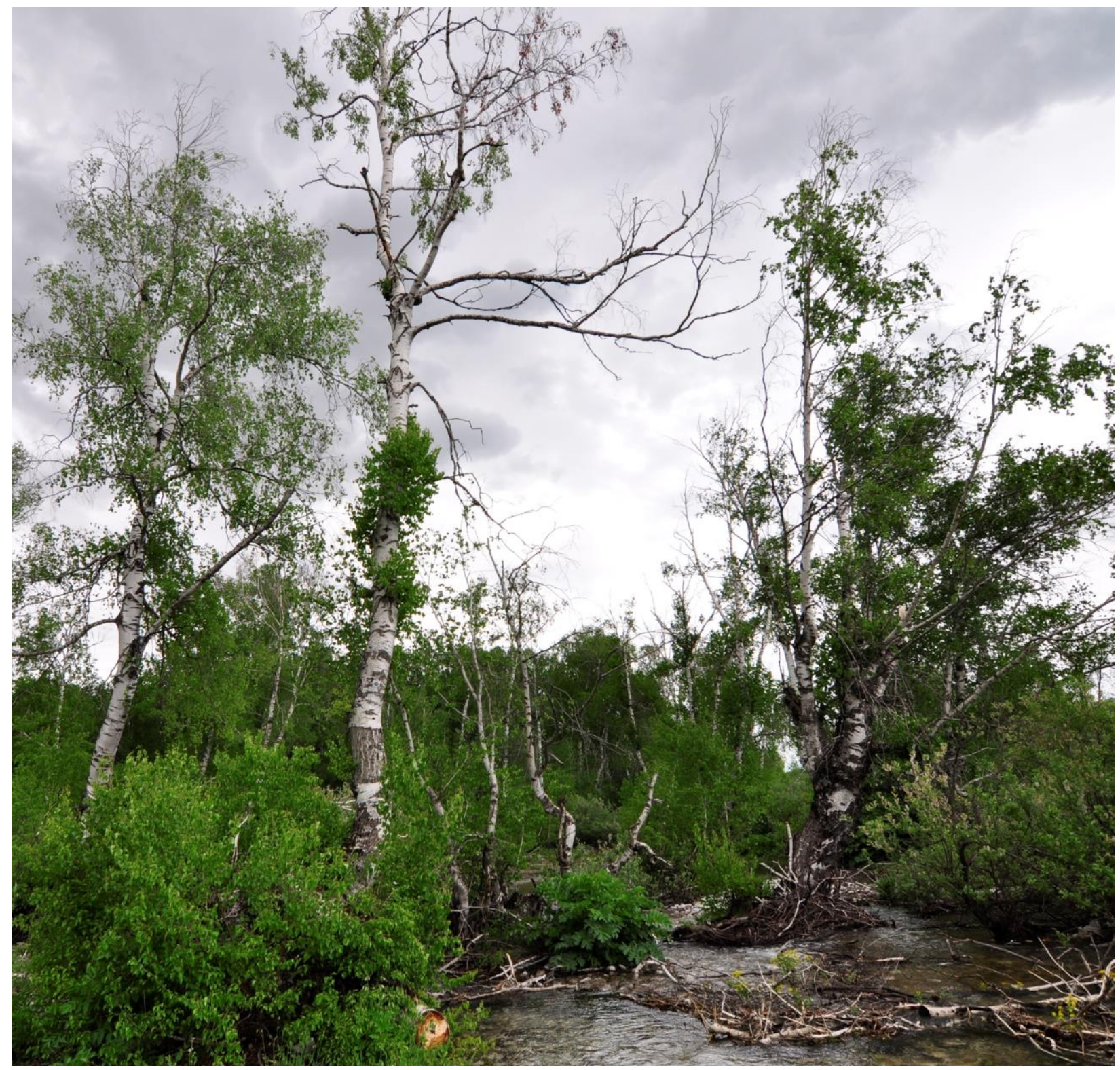

Figure 7. The stand in Yeşilyazı Village. It looks like a longoz forest (Foto: Murat Aygül)

3. Adaköy $\left(39^{\circ} 20^{\prime} 13^{\prime \prime} \mathrm{N}-39^{\circ} 05^{\prime} 14^{\prime \prime} \mathrm{E}\right.$ and $39^{\circ} 20^{\prime} 39^{\prime \prime} \mathrm{N}-39^{\circ} 06^{\prime} 38^{\prime \prime} \mathrm{E} /$ altitude is $\left.1290 \mathrm{~m}\right)$ : After the stand in Yeşilyazı Village, around Adaköy Betula pendula is represented with an open woodland and individual trees. Trees are about $20 \mathrm{~cm}$ in DBH and $15 \mathrm{~m}$ height. Woody species in understory vegetation Salix amplexicaulis, S.caprea, Amygdalus webby, Frangula dodonei subsp.pontica, Viburnum orientale. This stand is wider than that in Yeşilyazı, and length of one direction of the covered are is $2.000 \mathrm{~m}$ and lies in both sides of the Munzur River covering about 20 ha (Figure 9). Within this stand an area composed of only Betula pendula and Salix caprea, where the soil is waterlogged. These two stands of Betula pendula were proably one forest before and after constructing the Yeşilyazı Bridge and road, it was fragmented to two stands. 


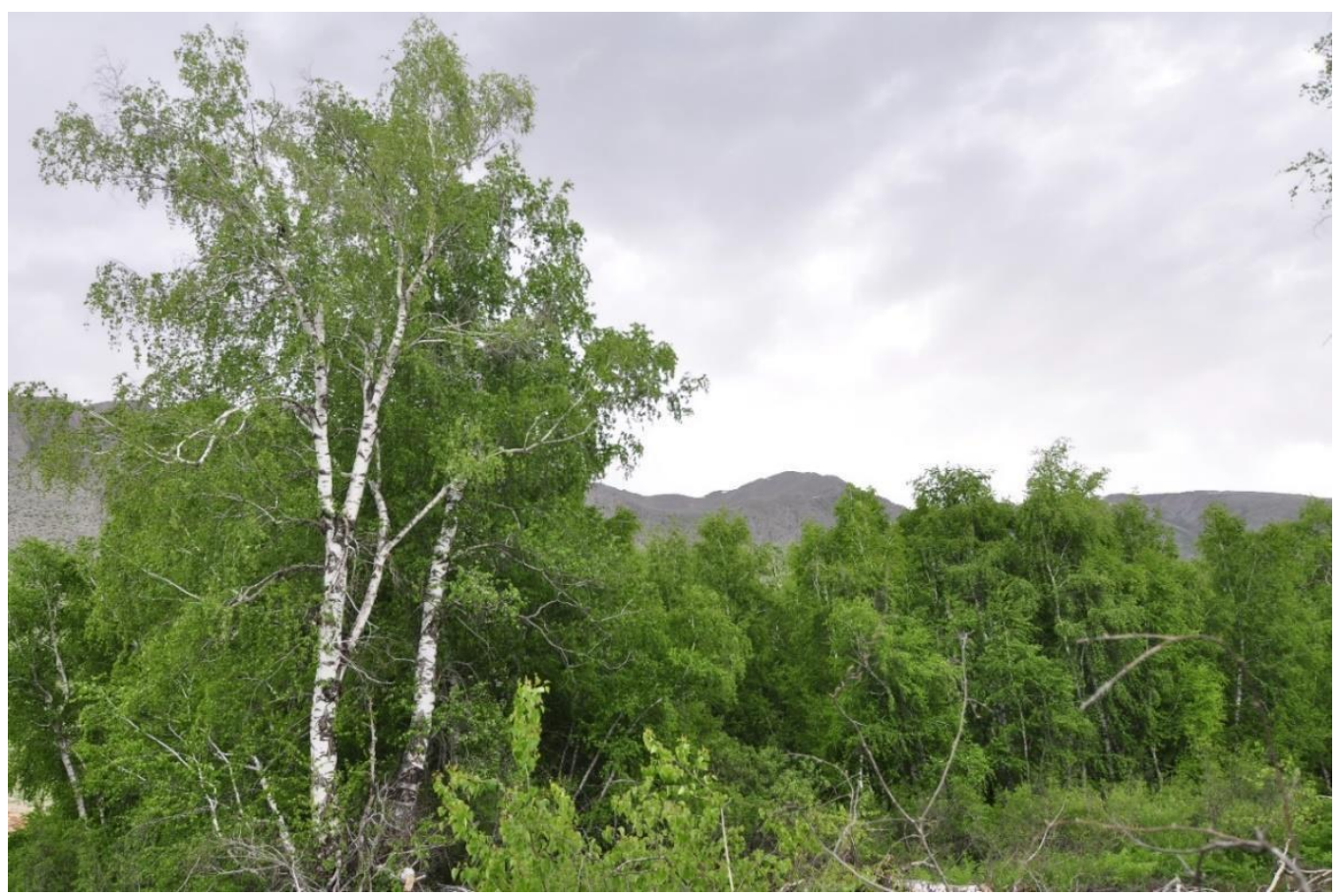

Figure 8. A stand of B.pendula from Yeşilyazı Village (Foto: Murat Aygül)

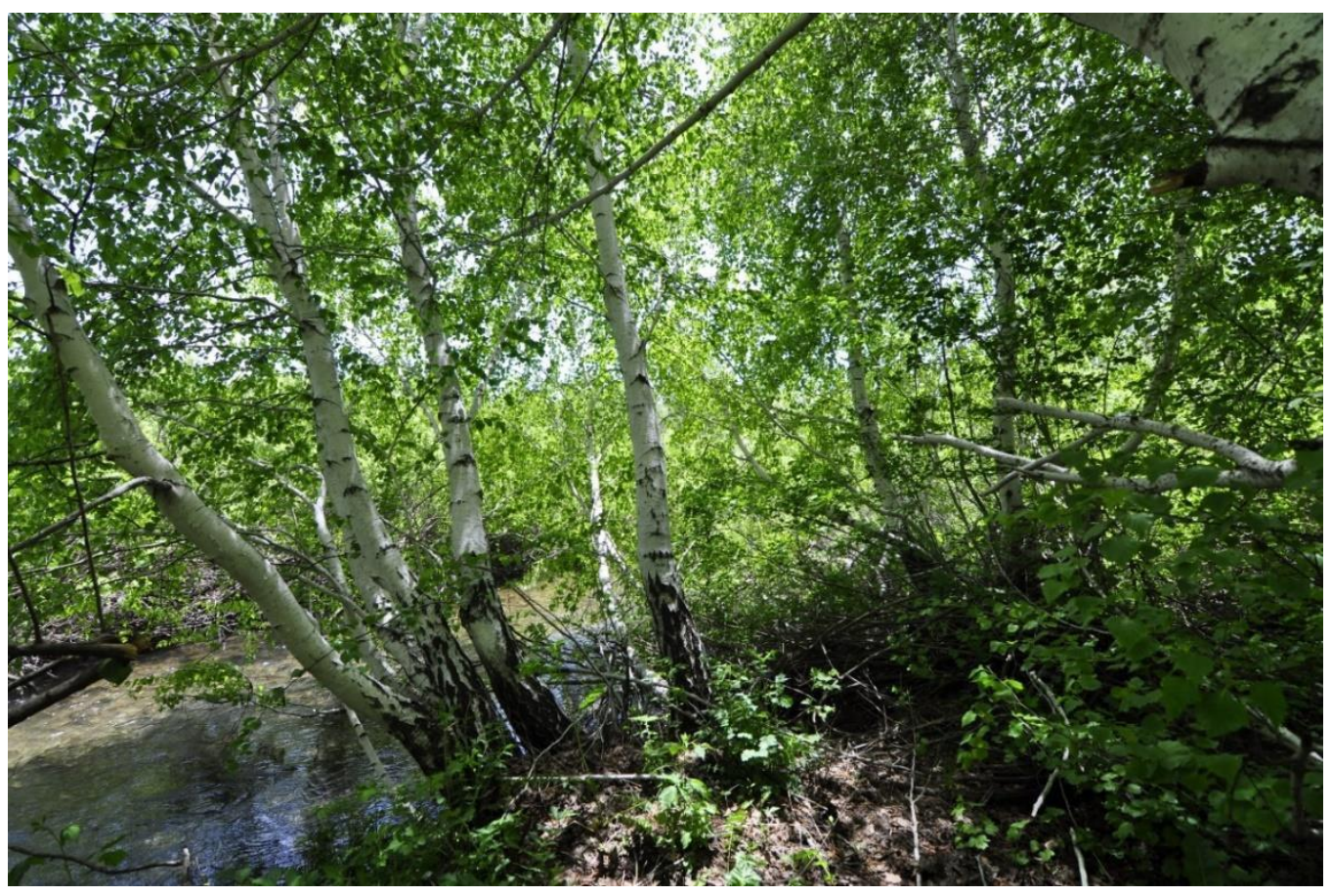

Figure 9. The stand in Adaköy Village. It looks like a longoz forest (Foto: Murat Aygül)

4. Joining point of Aksudere River to Munzur River ( $39^{\circ} 21^{\prime} 03^{\prime \prime} \mathrm{N}-39^{\circ} 15^{\prime} 25^{\prime \prime} \mathrm{E} /$ altitude is $\left.1280 \mathrm{~m}\right)$ : After 13-15 km from Adaköy, B.pendula trees were observed again, covering about $20 \%$ of the area. In this stand this species is represented with young trees and grows with Salix caprea, S.alba, S.amplexicaulis, Alnus glutinosa subsp.glutinosa and Acer tataricum.

5. Mercan River: This is one of the branches of the Munzur Valley. Differing from the other sites, about 4 $\mathrm{km}$ north of the river a Pinus sylvestris subsp.hamata stand was observed. Quercus petraea subsp.pinnatiloba is the other tree species in the stand. Here in this area B.pendula grows from the river up to the P.sylvestris stand (Altitude is $1230 \mathrm{~m}$ ).

6. The area between Marho Bridge and Joining Point of Mercan River $\left(39^{0} 20^{\prime} 56^{\prime \prime} \mathrm{N}-39^{\circ} 18^{\prime} 04^{\prime \prime} \mathrm{E} /\right.$ altitude is $1220 \mathrm{~m}$ ): There are B.pendula trees constituting a mixed stand and covering an area of about 30 ha 
with the species Alnus glutinosa subsp.glutinosa, Pyrus syriaca, Fraxinus angustifolia subsp. angustifolia, Salix alba, S.caprea, S.amplexicaulis, Populus nigra, Quercus branti, Tamarix gracilis and Acer tataricum. Tamarix gracilis is a rather different species found together with Betula pendula. In some parts of the area B.pendula and T.gracilis are found together (Figure 10). This finding can be evaluated that the area may be border for both these two species.

7. The last trees of Betula pendula were found in about $10 \mathrm{~km}$ far from Ovac1k $\left(39^{0} 21^{\prime} 11^{\prime \prime} \mathrm{N}-39^{0} 18^{\prime}\right.$ $52 " \mathrm{E}$

/ altitude is $1206 \mathrm{~m}$ ) (Figure 11). After this area the valley is narrow and the river runoff is accelerated. This natural structure of the valley may be a border of Betula pendula. From here down to Tunceli direction Populus tremula, Populus nigra, Alnus glutinosa subsp.glutinosa, Fraxinus angustifolia subsp.angustifolia, Crataegus azarolus, Rosa pulverulanta, Ulmus glabra, Salix alba, Acer tataricum, Acer platanoides, Acer monspessulanum subsp. ibericum, Juniperus oxycedrus (in slopes), Juglans regia, Prunus mahalep Cotynus coggyria, Lonicera sp. Quercus libani, Q. brantii, Q.cerris, Amelanchier rotundifolia, Pyrus elaeagnifolia, Pyrus syriaca, Amygdalus fenzliana, Cornus sanguinea, Vitis sp., and Tamarix gracilis grow throughout the valley. Distribution of Tamarix gracilis increase after B.pendula trees.

All woody plant taxa distributed with B.pendula trees by the river and on the slopes were given in Table 2. In riparian vegetation Salix alba, S. amplexicaulis, S.caprea, Populus nigra, Fraxinus angustifolia, Acer platanoides, A.tataricum and Alnus glutinosa constitute mixed stands with B.pendula trees. The other tree given in Table 2 grow in slopes and stony parts. This composition of the woody plants indicates that climate is semi dry in the slopes and growing site conditions does not support B.pendula. This species avoids from dry condition, and therefore, it can grow only river banks and expanding river bads in Munzur Valley.

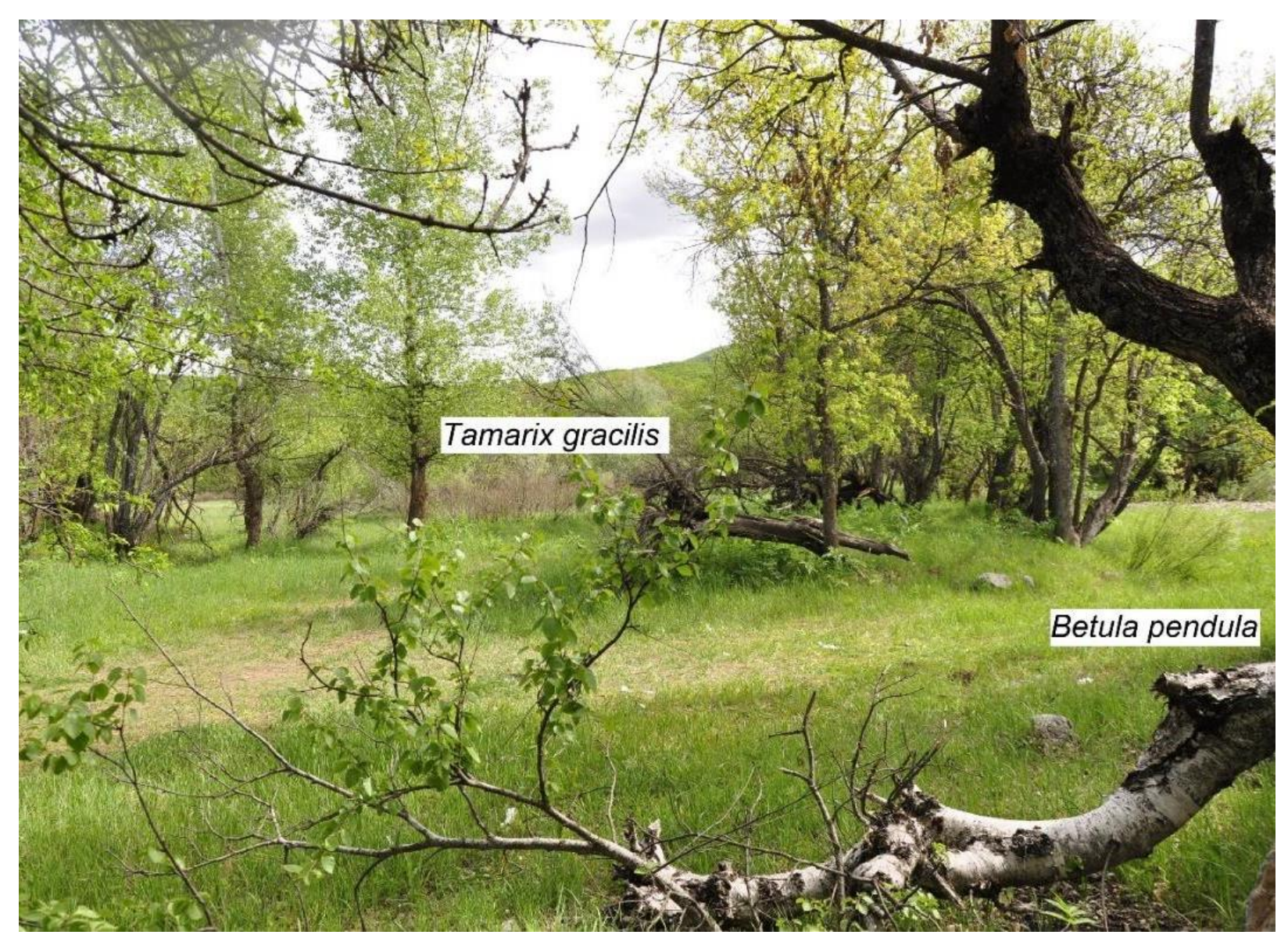

Figure 10. Betula pendula and Tamarix gracilis stand. This altitude is the lowest for Betula pendula and the highest for Tamarix gracilis (Foto: Murat Aygül) 
Table 2. The woody plants distributed with B.pendula and around the river

\begin{tabular}{|c|c|c|}
\hline No & Growing condition & Species \\
\hline 1 & \multirow{10}{*}{$\begin{array}{l}\text { River bank } \\
\text { (Riperian vegetation) }\end{array}$} & Acer platanoides \\
\hline 2 & & Acer tataricum \\
\hline 3 & & Alnus glutinosa subsp. glutinosa \\
\hline 4 & & Betula pendula \\
\hline 5 & & Fraxinus angustifolia subsp. angustifolia \\
\hline 6 & & Populus nigra \\
\hline 7 & & Salix alba \\
\hline 8 & & Salix amplexicaulis \\
\hline 9 & & Salix caprea \\
\hline 10 & & Tamarix gracilis \\
\hline 11 & \multirow{26}{*}{$\begin{array}{l}\text { Slope } \\
\text { (Woodland vegetation) }\end{array}$} & Acer monspessulanum subsp. ibericum \\
\hline 12 & & Amelanchier rotundifolia \\
\hline 13 & & Amygdalus fenzliana \\
\hline 14 & & Amygdalus webbii \\
\hline 15 & & Astragalus aureus \\
\hline 16 & & Celtis tournefortii \\
\hline 17 & & Colutea cilicica \\
\hline 18 & & Cornus songuinea \\
\hline 19 & & Cotinus coggygria \\
\hline 20 & & Crataegus azarolus \\
\hline 21 & & Ficus carica \\
\hline 22 & & Frangula dodeni subsp. pontica \\
\hline 23 & & Juglans regia \\
\hline 24 & & Juniperus oxycedrus \\
\hline 25 & & Lonicera sp. \\
\hline 26 & & Pinus silvestris \\
\hline 27 & & Prunus mahalep \\
\hline 28 & & Pyrus elaeagnifolia \\
\hline 29 & & Pyrus syriaca \\
\hline 30 & & Quercus brantii \\
\hline 31 & & Quercus cerris \\
\hline 32 & & Quercus libani \\
\hline 33 & & Quercus petraea subsp. pinnatiloba \\
\hline 34 & & Rosa pulverulanta \\
\hline 35 & & Ulmus glabra \\
\hline 36 & & Viburnum orientale \\
\hline
\end{tabular}

\section{Conclusion}

B.pendula is one of the relict species in Turkey. Because Turkey is located on the south of its distribution area, climate changes may seriously affect its distribution areas. The last glacial period showed that this species distributed to the west of Anatolia in cooler time, and to the east Anatolia in warmer period. The lowest elevation of its distribution areas in Turkey, Iran and Iraq is in the Munzur Valley. This part of Munzur Valley is a shelter for the species since it has a very special area. Trees here may reach up to $20 \mathrm{~m}$ height, and can only grow by the river and constitute wetland (waterlogged-like) forest with willow species. This shelter for the species should be protected with its water and soil. Here in this part of Munzur Valley the main factor is not only climate but also soil and high level of ground water. For sustainable forest management and species sustainability, this special ecosystem should be protected as a whole. 


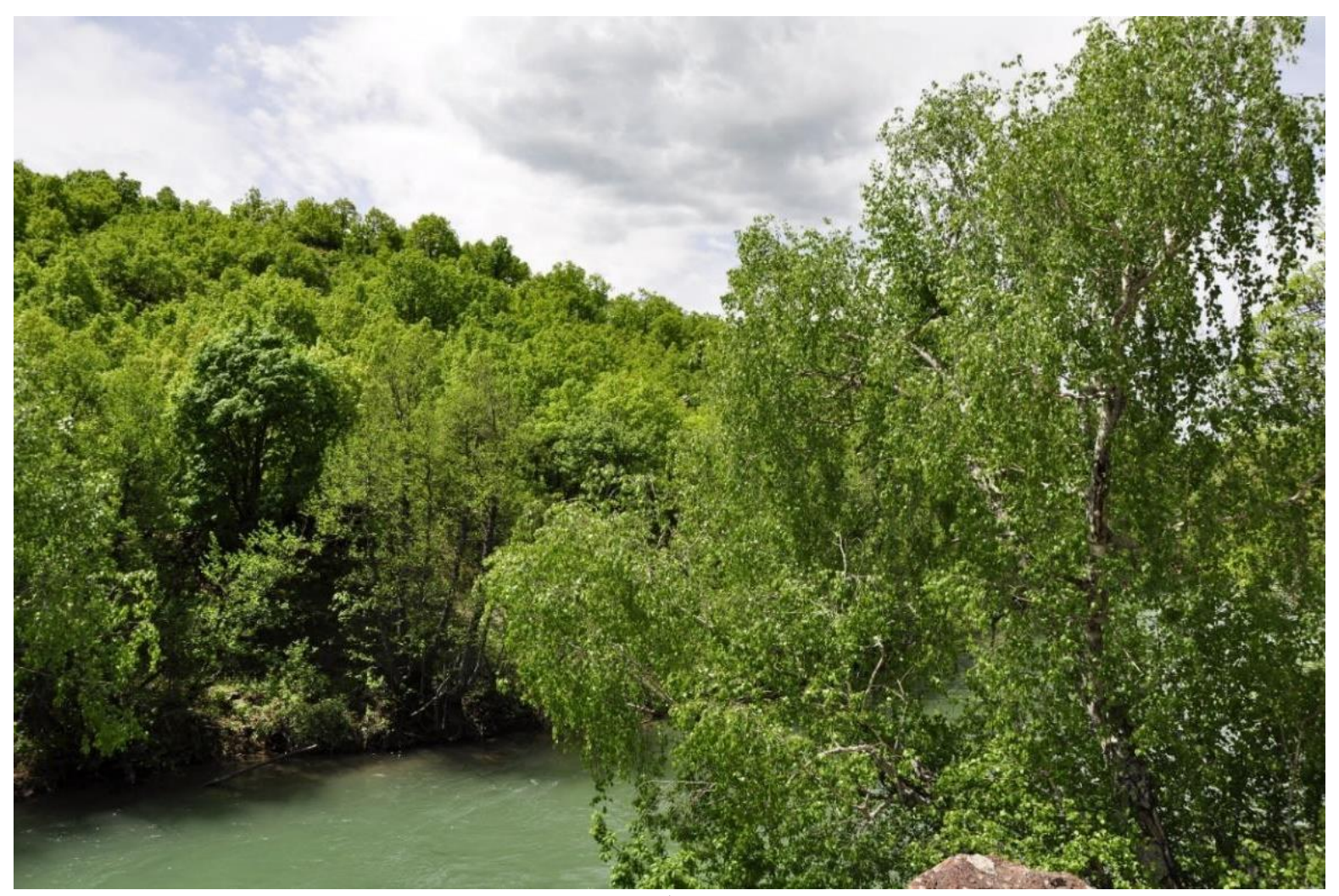

A

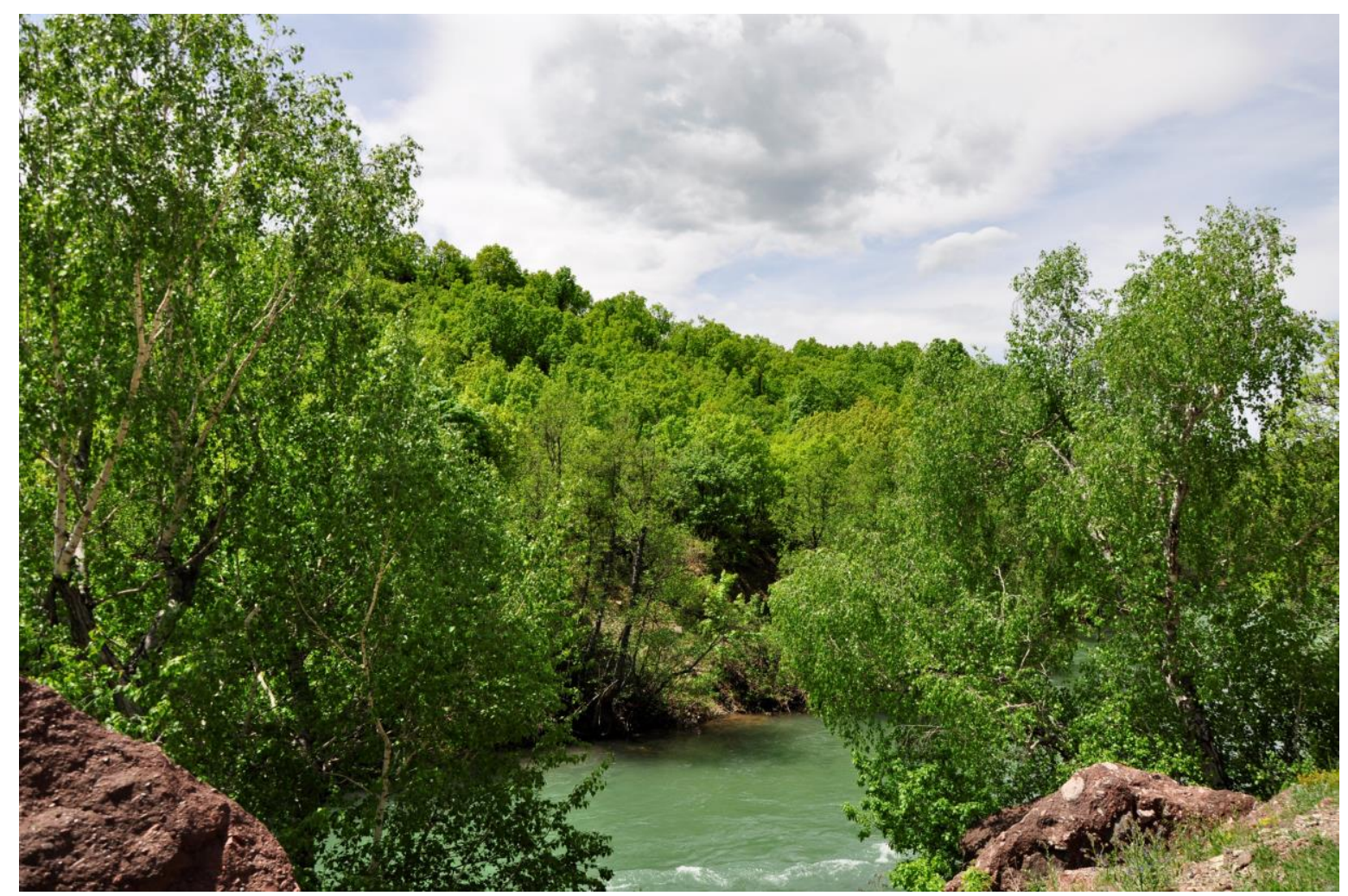

B

Figure 11. A-B) The last B.pendula trees on the Munzur River banks. Its altitude is $1.206 \mathrm{~m}$ a.s.l. (Foto: Aygül)Murat 


\section{Betula pendula türünün Geç Kuvaterner dönemi boyunca Türkiye'deki dağılımı ve en alt yayılış alanının özellikleri}

\section{Genişletilmiş Özet}

\section{Giriş}

Akdeniz, Iran-Turan ve Öksin-Kolşik flora bölgelerinin kesişme alanında bulunan Türkiye, Pinus sylvestris L., Quercus pontica, Betula pendula gibi bir çok ağaç türü ile çok sayıda otsu ve odunsu bitkinin yayılış alanlarının sınırını oluşturmaktadır. Bu konumundan dolayı ayrıca, 3000 civarında endemik bitki taksonuna sahiptir (Davis, 1965-1988; Güner ve diğ., 2000).

Araştırma konusu olan B.pendula (Siğilli huş, Salkım huş, Akhuş, Avrupa huşu (Yaltırık, 1988), Türkiye'de doğal yetişen 5 huş türünden en yaygın olanıdır. Davis (1982) ve Yaltırık (1988) B.pendula türünün Avrupa, Doğu ve Kuzeydoğu Anadolu, Batı Sibirya, Kafkas Dağları, İran'ın kuzey ve kuzeybatısı ile Irak'ın kuzeyinde yayılış yaptığını belirtmiştir. Bu yayılış alanı içerisinde özellikle Avrupa, Rusya ve Asya'nın kuzeyinde büyük ormanlar kurmakta; Ukrayna, Kazakistan, Rusya ve Avrupa'nın güneyi ile Türkiye, İran ve Irak'ta yerel yayılışlar yapmaktadır. Türün yayılış alanının güney sınırı İran'ın kuzeyindeki Elbruz Dağları olup burada 2750 m'lerde bulunmaktadır. Browicz ve Zielinski (1982) türün yayılış alanının kuzey sınırının 69. enlem, doğu sınırının da 105.boylam olduğunu belirtmiştir. Ülkemizde ise (Davis, 1982) Orta Anadolu ile Doğu-Kuzeydoğu Anadolu dağlarında, 14002750 m yükseltiler arasındaki soğuk ve nemli yetişme ortamlarında lokal yayılışlar yapmaktadır.

Huşların yayılış alanı ülkemizde genelikle volkanik araziler üzerindedir (Browicz ve Zielinski, 1982). Avcı (2004), dünyadaki yayılış alanının genişliği düşünüldüğünde bunun böyle olmadığını belirtmiştir. Huşlar özellikle ülkemizde volkanik arazilerde yayılmakla birlikte kuzey kesimlerdeki taban arazilerde geniş ormanlar kurmaktadır. B.pendula, soğuk iklim koşullarına dirençli olan ve kuraklıktan kaçınan bir ağaç türüdür. Yayılış alanının kuzey kesimlerinde deniz seviyelerine inerken güneye doğru soğuk koşulların hakim olduğu yüksek kesimlerde yaşayabilmektedir. Browicz ve Zielinski (1982) Türkiye, İran ve Irak gibi güneyde kalan yayılış alanlarının 1800-3000 m'ler olduğunu ve bu alanlarda da daha kısa boylu (10 m’ye kadar) ağaçlar ve dağınık meşcerler halinde yayıldığını belirtmiştir.

B.pendula türünün; ülkemiz, İran ve Irak’taki doğal yayılışının en alt sınırı Munzur Vadisindedir. Vadi çok zengin bir biyolojik çeşitliliğe sahip olduğundan 1971 yılında milli park ilan edilmiştir. Munzur Vadisi Milli Parkının, park olma kriterlerinin başlıcaları (1) çok zengin bitkisel çeşitliliğe sahip olması, (2) Türkiye'de çok düşük oranda bulunan B.pendula türünün yayılışının varlığı, (3) Munzur Vadisine ait alabalıkların varlığı ve (4) zengin bir hayvansal çeşitliliğin bulunmasıdır. Munzur Vadisi, sonraki yıllarda Özhatay ve diğ. (2005) tarafından Türkiye'nin 122 Önemli Bitki Alanından biri olarak belirlenmiştir. Davis (1965) tarafindan verilen karelaj sistemine göre B7 karesinde yer alan Munzur Vadisi ile ilgili detaylı floristik çalışmalar (Yıldırımlı, 1995; Davis, 1965-1985; Davis ve diğ., 1988; Vitek ve diğ., 2014, Karavelioğulları ve dĭg., 2014; Armağan, 2016; Yüce Babacan ve Eker, 2017) yapılmış ve 1522 taksonun varlığı saptanmıştır. Bunlar içerisinde 229 takson Türkiye için endemik, bunlar içinde de 46's1 Munzur Vadisine ait endemiktir.

Munzur Vadisinin odunsu florası da oldukça zengindir. Ormanlık alanlar huş (Betula pendula Roth, B. litwinowii Doluch.), meşeler (Quercus L.), ardiçlar (Juniperus excelsa M.Bieb., Juniperus oxycedrus L.), ceviz (Juglans regia L.), söğüt (Salix alba L.), kavak (Populus nigra L.), kızılağaç (Alnus glutinosa (L.) Gaertn.) ve akçaağaçlar (Acer tataricum L., ve A. platanoides L.) karışıma giren önemli ağaçlardır (Yıldırımlı, 1995)

Makalenin amacı; ülkemizin özellikle kuzeydoğusundaki dağlık ormanlarda karışıma giren, öncü ve rekabet gücü yüksek olan B.pendula türünün ülkemizdeki yayılışının, son buzul çağından günümüze kadar olan değişimlerini ve yakın doğu ile ülkemizdeki en düşük yayılış alanı olan Munzur Vadisindeki yetişme ortamlarını ekosistem bütünlüğ̈ açıdan değerlendirmektir. 


\section{Betula cinsinin Türkiye’nin Geç Kuvaterner Dönemi Boyunca Yayılışı}

Ülkemizde yapılan polen analizleri, son buzul çağından günümüze kadar ormanlarda meydana gelen değişimleri detaylı bir şekilde ortaya koymuştur. Bottema (1990), orman ağaçları içerisinde özellikle Betula polenlerinin son 13.000 yıllık dönemdeki değişimi üzerine odaklanmış ve türün yayılış alanlarındaki değişimi ortaya koymuştur (Şekil 1). Bottema (1990) ayrıca Betula polenlerinin özellikle Betula pendula türünü temsil ettiğini, türün öncü ve rekabet gücünün yüksek olduğunu belirtmiştir. $\mathrm{Bu}$ değişim 2.000 yıllık periyotlarla (Bottema, 1990) aşağıda özetlenmiştir:

- 14.000-12.000 BP: En eski Betula poleni kayıtları Yeniçağa Gölü’ne ait olup 13.500 yıl öncesine aittir. Bu göllerin bulunduğu yerlerin yükseltisi 700-1000 m'lerdir ve iklim Betula yayılışı için elverişli olmaya başlamıştır. $\mathrm{Bu}$ dönemde Betula ağaçları 700-800 m yükseltilerdeki ağaçsız alanlara doğru yayılmaya başlamıştır.

- 12.000-10.000 BP: Bu dönemde Betula polenleri Anadolu'nun doğu ve batısında yaygındır. Batıda Abant ve Yeniçağa Gölü, Karamık Bataklığı, Konya-Akgöl ve Söğüt Göllerindeki çökellerde polen yoğunluğu en yüksek seviyesinde çıkmıştır. Polen sonuçları, Betula ormanlarının bu dönemde yoğun olduğunu ve 700-800 m yükseltilerden başlayarak yükseklere doğru yayıldığını göstermiştir. Bu dönemde iklim buzul çağından yeni çıkılmış, günümüze göre daha soğuk ve nemli olduğundan dolayı türün yayılışı için optimumdur (Şekil 1).

- 10.000-8.000 BP: Bu dönemin başlarında en yüksek seviyesine çıkan polen yoğunluğu, dönemin sonuna doğru azalmaya başlamıştır. Başlangıçta huşun dominant olduğu alanlarda, sonrasında göknar türleri hakim olmaya başlamıştır (Şekil 1).

- 8.000-6.000 BP: Bu dönemde Betula, Anadolu'nun batısında (36. boylamın batısında) hızla azalmaya başlamıştır. Buna karşın doğuda (Nemrut Dağı-Sögüttlü-, Van Gölü ile Kuzey İran'daki Urmia Gölü çevresinde (Bottema, 1986) önemli miktarda polen tespit edilmiş olup Betula ormanlarının batıdan doğuya doğru kaydığını göstermektedir. Bu durum, sıcaklığın artmaya başladığının bir göstergesi olarak değerlendirilebilir (Şekil 1).

- 6.000-4.000 BP: Bu dönem, Betula polenlerinin doğuda azalmaya başladığı, buna karşın Abant çevresinde tekrar görüldügü dönemdir (Şekil 1).

- 4.000-2.000 BP: Bu dönemin ortalarında (4.000'den-3.000 BP'e kadar) Betula, Kuzeybat1 Anadolu'da tekrar artmıştır. Bottema ve Woldring (1990), bu dönemi "Beyşehir Yerleşim Safhası" olarak adlandırmış ve Betula için iklimin tekrar kuzeybatıda optimum olduğunu belirtmiştir (Şekil 1).

- 2.000-Günümüz: Betula Anadolu'nun batısından tamamen çekilmiş ve Orta Anadolu'da sadece Kayseri-Erciyes Dağının $2400 \mathrm{~m}$ yükseltilerinde yayılış alanı kalmıştır. Buna karşın Anadolu'nun kuzeydoğusundaki iklimin elverişli olduğu yüksek kesimlerde lokal yayılış alanlarına sığınmıştır (Şekil 1).

\section{Betula pendula türünün genel ve ülkemizdeki yayılışı}

Betula pendula en geniş yayılışlı huş türü olup Asya ve Avrupa Kıtası'nın kuzeyi boyunca çok geniş bir yayılış alanina sahiptir. Yayılış alanının kuzey kesimlerinde yoğun ve kesintisiz ormanlar kurarken, güneye doğru (Avrupa ve Rusya'nın güneyi, Türkiye, İran, Irak, Gürcistan, Ukrayna, Ermenistan ve Hazar Denizi çevresinde lokal ve parçalı yayılış alanları vardır (Şekil 2). Kuzeyde deniz seviyesine kadar inerken yayılış alanının güneyinde 1400-2750 m yükseltilerde yetişmektedir. Dünya üzerindeki en güney yayılış alanı olan İran'ın kuzeyinde 2750 m'lerde yetişmektedir.

Türkiye'deki yayılışı ise 1200-2750 m'ler arası olup genel olarak 2.000 m'nin üzerindedir. Türkiye'deki yayılışının en alt sınırını 1.200 m'lerde Munzur Vadisi oluşturmaktadır. Davis (1982)'ye göre yayılış alanları: A7 Trabzon: Değirmen Dere, 2100 m; A8 Erzurum: Kop Dağı Geçidi, 2350 m; A9 Çoruh: Ardanuç, Sakaltutan Dağı, 2230 m; B5 Kayseri: Erciyes Dağı, 2800 m; B7 Tunceli: Ovacik, Munzur Nehrinin kaynağı, B8 Muş: Varto, Bingel Dağı etekleri, 1585 m; B9 Bitlis: Nemrut Krateri, 2400 m; B10 Ağrı: Küçük Ağrı Dağı'nın batısı, 2500 m. (Şekil 3). Herbaryum kayıtlarında Munzur 
Nehrinin kaynağı en alt yükselti olarak görülmesine karşın yapılan gözlemler ve tespitler sonucunda bu vadinin aşağılarında $1.206 \mathrm{~m}$ yükseltilerde de yer yer meşcere yer yer de bireyler halinde bulunduğu tespit edilmiştir. Mayer ve Aksoy (1998), türün bulunduğu Küçük ve Büyük Ağrı Dağı'nın 2200-2780 $\mathrm{m}$ yükseltilerinde Sorbus aucuparia, Berberis integerrima, Juniperus communis, Ribes orientale, Rosa pimpinellifolia, Cotoneaster sp., Daphne oleoides, Epilobium angustifolium ve Dactylis glomerata ile karışıma girdiğini belirtmiş̧ir. Peşmen (1973) ise Van Gölü'nün batısında yer alan Nemrut Kraterinde türün çalı formundaki bireylerinin 2600-2800 m'lerde görüldüğünü ve Juniperus communis subsp. nana, Cotoneaster nummularia, Crataegus curvisepala, Rosa pulverulanta, Astragalus aureus ve A.eriocephalus ile karışıma girdiğini belirtmiştir (Peşmen, 1973).

\section{Betula pendula türünün yayılış alanlarının iklim özellikleri}

Köppen iklim sınıflandırmasına (Dönmez, 1984) göre, en soğuk ayın ortalama sıcaklığı $-3{ }^{\circ} \mathrm{C}$ 'inin altında ve en sıcak ayın ortalamasının $10^{\circ} \mathrm{C}$ 'nin üzerinde olması nedeniyle "D iklimler kuşağı"na girmektedir. Bu kuşaktaki iklimlerin bir özelliği de toprağın aylarca karla örtülü olması ve kış aylarında donmasıdır. Her mevsim yağışı olduğundan iklim tipi Dfc (kışı şiddetli yazı kısa serin, her mevsimi yağışı iklim) olarak belirlenmiştir. Köppen iklim sınıflandırmasına göre tüm yayılış alanları aynı iklim tipine girmektedir.

De Martonne iklim sınıflandırmasına göre (DMI, 1972) ise B.pendula türünün Türkiye'deki yayılış alanlarının farklı iklim tiplerine sahip olduğu belirlenmiştir (Tablo 1; Şekil 3). Kayseri, Trabzon, Ağrı, Tunceli ve Erzurum "step-nemli iklim arası" bir iklim tipi hakim iken Bitlis ve Muş’ta yarı nemli, Artvin'de ise nemli bir iklim tipi vardır. Minimum sıcaklıkların ortalamasının en düşük olduğu yer $11,9{ }^{\circ} \mathrm{C}$ ile Artvin iken maksimum sıcaklık ortalamalarının en yüksek olduğu yer $27.7{ }^{\circ} \mathrm{C}$ ile Munzur Vadisidir (Şekil 3). Artvin'de ayrıca her mevsim yüksek yağış olup su noksanlığı bulunmamaktadır. Buna karşın, Munzur Vadisinde yaz döneminde yağış diğer yetişme ortamlarına göre daha düşüktür.

Sıcaklığın en düşük olduğu ocak ayı ile en yüksek olduğu ağustos ayındaki maksimum, ortalama ve minimum sıcaklık değerleri incelendiğinde en sıcak yetişme alanının Tunceli-Munzur Vadisi olduğu görülmektedir (Şekil 4). Genel olarak, B.pendula ağaçlarının yetişme ortamlarındaki en sıcak ay olan ağustos ayındaki maksimum sıcaklıkların ortalaması yaklaşık $25^{\circ} \mathrm{C}$, ortalama sıcaklıklar $15-20{ }^{\circ} \mathrm{C}$ ve minimum sıcaklıklar da $10^{\circ} \mathrm{C}$ civarındadır. En soğuk ay olan Ocak ayındaki maksimum sıcaklıkların ortalamas $1-2{ }^{\circ} \mathrm{C}$, ortalama sicaklıklar $(-4)-\left(-8{ }^{\circ} \mathrm{C}\right)$ ve minimum sicaklıklar da $(-8)-\left(-12{ }^{\circ} \mathrm{C}\right)$ arasinda değişmektedir. Yayılış alanları içerisinde en soğuk yetişme ortamı Muş’ta bulunan meşcereleridir. Yayılış alanları minimum sıcaklık açısından karşılaştırıldığında, en düşük yetişme ortamı olan TunceliMunzur Vadisindeki minimum sıcaklık ortalamalarının diğerlerine göre daha ılıman olduğu görülmüş̧ür.

\section{Bulgular ve Tartışma}

B.pendula, Kuzey Yarımkürenin çok geniş bir alanında deniz seviyesinden 3000 m'lere kadar yayılış yapmaktadır. Ülkemizde ise 1200-2800 m arasında yetişmektedir. Gözlemlerimiz türün İran, Irak ve Türkiye'deki en düşük yükseltiye indiği yerin Munzur Vadisi olduğunu ve vadi boyunca özellikle vadinin genişleyip su akışının yavaşladığı Ovacık çevresinde yayılış yaptığını ortaya koymuştur (Şekil 5). Türün güney enlemlerdeki en alt yayılış alanı olan Munzur Vadisi'ndeki bulunduğu yerler aşağıda daha detaylı bir şekilde verilmiştir (Şekil 6):

1. Kırkgözler/Munzur Gözeleri ( $39^{0} 19^{\prime} 51^{\prime \prime} \mathrm{N}-39^{\circ} 03^{\prime} 22^{\prime \prime}$ E / denizden yüksekliği $1333 \mathrm{~m}$ ): Gözelerin çevresinde genç Betula pendula bireyleri bulunmaktadır. Bu alandaki ağaçların çapları 8 cm'nin altında olup ağaçlandırma sahası olma olasılığı da bulunmaktadır. Tür, bu alanda Quercus cerris, Ulmus glabra, Acer monspessulanum subsp. ibericum, Populus nigra, Salix alba ve Juglans regia ile birlikte bulunmaktadır. B.pendula, sadece nehir nehir kenarında bulunurken akçaağaç, meşe ve ceviz türleri vadinin çevresinde yayılmaktadır.

2. Yeşilyazı Köyü $\left(39^{\circ} 20^{\prime} 02^{\prime} ’ \mathrm{~N}-39^{\circ} 04^{\prime} 21^{\prime \prime} \mathrm{E}\right.$ ve $39^{\circ} 20^{\prime} 12^{\prime \prime} \mathrm{N}-39^{0} 04^{\prime} 54^{\prime \prime} \mathrm{E} / \mathrm{denizden}$ yüksekliği $1308 \mathrm{~m}$ ): Burada bulunan meşcere Amenajman Planlarında yer almakta olup yaklaşık $150 \mathrm{~m}$ genişlik ve $800 \mathrm{~m}$ uzunluğunda, nehir boyunca 3 hektarlık bir alan kaplamaktadır. Ziyaret köyünden Yeşilyazı köyüne doğru yaklaşık $800 \mathrm{~m}$ mesafede bulunan 
meşcere, 17 Mayıs 2017 tarihinde halen büyük oranda su altında olup longoz ormanı karakterindedir ve taban suyu seviyesi oldukça yüksektir. Meşcere altında herhangi bir odunsu flora bulunmayıp B.pendula, Salix alba ile birlikte karışıma girmektedir (Şekil 7-8).

3. Adaköy $\left(39^{\circ} 20^{\prime} 13^{\prime} ’ \mathrm{~N}-39^{\circ} 05^{\prime} 14^{\prime \prime} \mathrm{E}\right.$ ve $39^{\circ} 20^{\prime} 39^{\prime}{ }^{\prime} \mathrm{N}-39^{\circ} 06^{\prime} 38^{\prime}{ }^{\prime} \mathrm{E} /$ denizden yüksekliği $1290 \mathrm{~m}$ ): Bu meşceredeki ağaçlar seyrek bir orman yapısı oluşturmakta olup yaklaşı1k $20 \mathrm{~cm}$ çapında ve $15 \mathrm{~m}$ boyundadır (Şekil 9). Browicz ve Zielinski (1982) güney alanlarda ağaçların 10 m'yi geçmediğini belirtse de, longoz karakterinde olan Munzur Vadisindeki yayıllıs alanlarında $20 \mathrm{~m}$ boya ulaşan ağaçlar görülmüştür. Üst meşcere Betula pendula ve Salix alba ağaçlarından oluşurken orman altı Salix amplexicaulis, S.caprea, Amygdalus webbi, Frangula dodnei subsp.pontica, Viburnum orientale türlerinden oluşmaktadır. Yeşilyazı köyünde bulunan meşcerenin devamı niteliğinde olduğu düşünülen bu meşcere Yeşilyazı Köprüsü ve yolu ile ikiye ayrılmış durumdadır.

4. Aksudere - Munzur Nehrine Katılım Noktası $\left(39^{0} 21^{\prime}\right.$ 03'’ $\mathrm{N}-39^{0} 15^{\prime}$ ' 25'”E / denizden yüksekliği $1280 \mathrm{~m}$ ): Adaköy'den 13-15 km sonra B.pendula ağaçları Munzur nehri kenarlarında tekrar görülmeye başlamıştır. Bu alanın yaklaşık \%20'si Betula pendula türü ile kaplıdır. Genç ağaçlarla temsil edilen B.pendula; Salix caprea, S.alba, S.amplexicaulis, Alnus glutinosa subsp.glutinosa ve Acer tataricum gibi türlerle birlikte bulunur.

5. Mercan Nehri (Denizden yüksekliği 1230): Munzur Vadisinin bir kolu olup yaklaşık $4 \mathrm{~km}$ kuzeyinde bir sarıçam (Pinus sylvestris subsp.hamata) meşceresi bulunmaktadır. B.pendula nehirden sarıçam meşceresine kadar bireyler halinde yayılış yapmaktadır. Quercus petraea subsp.pinnatiloba ise karışıma giren ağaç türüdür.

6. Marho Köprüsü ve Mercan Nehrinin Birleşme Noktası Arasındaki Yayılış Alanı (39 20 20 56' 'N - 39 $18^{\circ}$ ' 04' 'E / denizden yüksekliği $1220 \mathrm{~m}$ ): Yaklaşık 30 ha büyüklüğünde bir meşcere olup B.pendula ağaçları da karışıma girmektedir. Alnus glutinosa subsp.glutinosa, Pyrus syriaca, Fraxinus angustifolia subsp.angustifolia, Salix alba, S.caprea, S.amplexicaulis, Populus nigra, Quercus branti, Tamarix gracilis ve Acer tataricum gibi türler karışımı oluşturan ağaç ve çalılardır. Ekolojik olarak daha alt yükseltilerde yayılış yapan Tamarix gracilis burada B.pendula ile birlikte bulunmakta olup (Şekil 10) bu durum her iki türün de yayılışlarının sinırlarında olduğuna işaret etmektedir.

7. Vadi içerisinde Ovacık ilçesinden Tunceli’ye doğru uzanan nehir kenarındaki son B.pendula ağacı Ovacık'tan $10 \mathrm{~km}$ sonra, vadinin daralmaya başladığı noktadadır $\left(39^{0} 21^{\prime} 11^{\prime}\right.$ ' $\mathrm{N}-39^{\circ} 18^{\prime}$ 52'’E / denizden yüksekliği $1206 \mathrm{~m}$ ) (Şekil 11). Bu ağaçlardan sonra vadi daralmaya başlamakta ve su akışı hızlanmakatadır. Bu doğal oluşum B.pendula'nın doğal yayılışını sınırlandıran bir faktör olabilir. Bu son B.pendula ağaçlarından sonra vadi boyunca Populus tremula, Populus nigra, Alnus glutinosa subsp.glutinosa, Fraxinus angustifolia subsp.angustifolia, Crataegus azarolus, Rosa pulverulanta, Ulmus glabra, Salix alba, Acer tataricum, Acer platanoides, Acer monspessulanum subsp. ibericum, Juniperus oxycedrus (yamaçlarda), Juglans regia, Prunus mahalep, Cotynus coggyria, Lonicera sp. Quercus libani, Q. brantii, Q.cerris, Amelanchier rotundifolia, Pyrus elaeagnifolia, Pyrus syriaca, Amygdalus fenzliana, Cornus sanguinea, Vitis sp. ve Tamarix gracilis ağaçları meşcere oluşturmakta ve özellikle Tamarix gracilis türünün yoğunluğu artmaktadır.

B.pendula ağaçlarının bulunduğu yetişme ortamları ve çevresinde bulunan odunsu bitkiler Tablo 2'de verilmiştir. Dere vejetasyonu (riperian vejetasyon) B.pendula ile birlikte, Salix alba, $S$. amplexicaulis, S.caprea, Populus nigra, Fraxinus angustifolia, Acer platanoides, A.tataricum ve Alnus glutinosa türlerinden oluşmaktadır; diğer türler ise yamaçlardaki eğimli ve taşlı koşullarda yetişmektedir.

B.pendula, kurak koşullara dayanıksız bir tür olduğundan, Munzur Vadisinde sadece dere kenarlarında ve vadinin genişlemiş, su akışının yavaşladığı, derin topraklı, taban suyu seviyesi yüksek ve longoz karakterinde olan kısımlarında yetişebilmektedir.

\section{Sonuç}

B.pendula, yayılışının güney sınırları olan Türkiye'de relikt bir tür olup yüksek dağlık kesimlerdeki soğuk koşullara sığınmıştır. Son buzul çağından hemen sonra tüm Anadolu'da, özellikle batıda yayılış yaparken son 2.000 yıllık dönem içerisinde batıdan tamamen çekilmiş ve asıl yayılışını 
Doğu ve Kuzeydoğu Anadolu'nun dağlarında yapmıştır. Bu durum türün, güney sınırında olmasından dolayı iklim değişimlerine oldukça duyarlı olduğunu göstermektedir.

Türün, Türkiye, İran ve Irak gibi güney yayılış sınırı içerisindeki en düşük yükseltide bulunduğu yer 1206 m ile Munzur Vadisindeki nehir çevresidir. Özellikle Ovacık ilçesi çevresinde bulunan ve vadinin hafif genişlediği, düz olmasından dolayı su akışının yavaşladığı ve alüvyon birikimiyle derin topraklı ve taban suyu seviyesinin çok yüksek olduğu bir ortamın oluşması burada kuraklığa hassas olan B.pendula için bir yaşam ortamı oluşturmuştur. Yer yer longoz ormanı karakterinde bulunan B.pendula meşcrelerinde ağaç boyları 20 m'yi geçmektedir. O nedenle, B.pendula için bir sığınak konumunda olan bu özel alanın sürdürülebilir bir ekosistem olarak ve türün devamlılığ 1 açısından alanıyla birlikte korunmasi gereklidir.

\section{Acknowledgement}

We thank Murat Aygül for the photographs of the species and stands.

\section{References}

Armağan, M., (2016). Gypsophila munzurensis (Caryophyllaceae), a new species from Tunceli (Turkey). Phytotaxa275(2):175-180

Avcı, M., (2004). İç Anadolu Bölgesi Ormanlarının Son Sığınakları Karacadağ ve Karadağ Volkanlarının Bitki Örtüsü. Çantay Kitabevi. İstanbul

Bottema, S., (1986). A late Quaternary pollen diagram from Lake Urmia (north-western Iran).Reviewof Palaeobotany andPalynology 47:241-261.

Bottema, S., (1990). Notes on the history of the genus Betula in Turkey during the Late Quaternary. Ecologia Mediterranea. V.16, pp. 145- 150.

Bottema, S., Woldring, H., (1984 (1986). Late Quaternary vegetation and climate of southwestern Turkey, Part II. Palaeohistoria 26: 123-149

Browicz, K., (1982). Betula L. In: Flora of Turkey and the East Aegean Islands, Vol. 7, ed. PH. Davis, Edinburgh: Edinburgh University Press, p. 689

Browicz, K., Zielinski, J., (1982). Chorology of Trees and Shrubs in South-West Asia and Adjacent Regions, vol. 1. - Polish Scientific Publishers, Warsaw, PoznaM.

Davis, P.H., (1965-1985). Flora of Turkey and the East Aegean Islands. V.1-10. Edinburgh University Press.

Davis, P.H., Miller R.R., Tan K., (1988). Flora of Turkey and the East Aegean Islands, 10. Edinburgh Univ. Press. Edinburgh

DMİ, (1972). Türkiye İklim Tasnifi (De Martonne Metoduna Göre). Ankara

Dönmez, Y., (1984). Umumi Klimatoloji ve İklim Çalışmaları İ.T.Ü. Yayın No: 2506, Coğrafya Enstitüsü Yayın No: 102

Güner, A., Özhatay, N., Ekim, T., Başer, K.H.C. (eds.) (2000). Flora of Turkey and the East Aegean Islands. V.11. Edinburgh University Press.

Karavelioğulları, F.A., Yüce, E., Başer, B., (2014). Verbascum duzgunbabadagensis (Scrophulariaceae), a new species from eastern Anatolia, Turkey. Phytotaxa 181 (1): 047-053

Mayer, H., Aksoy, H., (1998). Türkiye Ormanları (Walder der Türkei), (Çeviri: H. Aksoy-G. Özalp). Türkiye Cumhuriyeti, Orman Bakanlığı, Batı Karadeniz Ormancılık Araşıtırma Enstitüsü Müdürlügü̈, Bolu

Özhatay, N., Byfield, A., Atay, S., (2005). Türkiye'nin Önemli Bitki Alanları. Mas Matbaacıllk, İstanbul.

Peşmen, H., (1973). A Study on the Flora of Nemrut Dagi (Bitlis). Proc. 1st. Symp. Abies equi-trojani and Turkish Flora: 271-287

Vitek, E., Yüce, E., Ergin, C., (2014). Gundelia dersim and Gundelia munzuriensis (Compositae), two new species from Turkey. Phytotaxa 161(2): 130-138 
Yaltırık, F., (1988). Dendroloji Ders Kitabı, Angiospermae (Kapalı Tohumlular), İstanbul Üniversitesi Orman Fakültesi Yayınları, İstanbul

Yıldırımlı, Ş., (1996). Flora of Munzur Dağları (Erzincan-Tunceli). Ot Sist. Bot. Dergisi 2 (1): 1-78

Yüce Babacan, E., Eker, İ., (2017). Munzur Vadisi (Tunceli) ve yakın çevresinin geofit florası. Bağbahçe Bilim Dergisi, 4(1): 31-49

Zeist. W. Van., Timmers, R.W., Bottema, S., (1968 (1970). Studies of modern and Holocene pollen precipitation in southeastern Turkey. Palaeohistoria 14: 19-39.

Submitted: 03.07.2017; Accepted: 27.08.2017 